\title{
Effects of site preparation treatments before afforestation on soil carbon release
}

\author{
Jianlei Wang ${ }^{\mathrm{a}, \mathrm{b}}$, Huimin Wang ${ }^{\mathrm{a}, *}$, Xiaoli Fu ${ }^{\mathrm{a}, *}$, Mingjie Xu ${ }^{\mathrm{a}}$, Yidong Wang ${ }^{\mathrm{c}}$ \\ ${ }^{a}$ Qianyanzhou Ecological Research Station, Key Laboratory of Ecosystem Network Observation and Modeling, Institute of Geographic Sciences and Natural Resources Research, \\ Chinese Academy of Sciences, No. 11A, Datun Road, Chaoyang District, Beijing 100101, China \\ ${ }^{\mathrm{b}}$ University of Chinese Academy of Sciences, Beijing 100039, China \\ ${ }^{\mathrm{c}}$ Tianjin Key Laboratory of Water Resources and Environment, Tianjin Normal University, Tianjin 300387, China
}

\section{A R T I C L E I N F O}

\section{Article history:}

Received 30 October 2015

Accepted 10 November 2015

Available online 23 November 2015

\section{Keywords:}

Soil basal respiration

Brush clearing

Controlled burning

Overall soil preparation

Spot soil preparation

Subtropical forest

\begin{abstract}
A B S T R A C T
Site preparation, as an important procedure before afforestation, can affect soil $\mathrm{C}$ release. However, the effect of site preparation on soil $C$ release has not been sufficiently investigated. Two site clearing treatments (brush clearing and controlled burning) followed by three soil preparation treatments (overall soil preparation, spot soil preparation, and no soil preparation (control)) were carried out in subtropical China. Soil basal respiration $\left(R_{\mathrm{S}}\right)$ and $\mathrm{C}$ release of biomass burning were measured as soil $\mathrm{C}$ release on an area basis from March 2011 to March 2013. The site preparations changed the soil $C$ release in the first year but had no effects in the second year. Compared with brush clearing (control), controlled burning (control) significantly increased the annual soil C release (decreased $R_{\mathrm{S}}$ but increased C release of biomass burning) during the first year. Within the brush clearing plots, overall soil preparation significantly increased the $R_{\mathrm{S}}$ rate over eight months and resulted in an increase in annual soil $C$ release during the first year compared to the no soil preparation. In contrast, spot soil preparation increased the $R_{\mathrm{S}}$ rate only for three months and did not affect the annual soil $C$ release during the first year relative to the no soil preparation. In the controlled burning plots, both overall and spot soil preparation increased the $R_{\mathrm{S}}$ rate across six months, but only overall soil preparation caused a significant increase in the annual soil $C$ release. Our study suggests that minimizing the disturbance of the site preparation would decrease soil $\mathrm{C}$ release. Concluding, the spot soil preparation followed brush clearing is a good choice for site preparation in term of soil $\mathrm{C}$ storage.
\end{abstract}

(C) 2015 Elsevier B.V. All rights reserved.

\section{Introduction}

In the context of global climate change, how to enhance $\mathrm{C}$ sequestration and reduce $C$ emission are major subjects. The Kyoto Protocol and IPCC Report (2007) suggested that afforestation is a potentially useful approach to mitigate the increasing atmospheric $\mathrm{CO}_{2}$ concentration (Berthrong et al., 2012), and the area of forest plantations is rapidly increasing throughout the world (Nouvellon et al., 2008). In China, forestation has been carried out as an effective measure against environment degradation since the 1970s and has brought a remarkable increase in the forest $\mathrm{C}$ stock of 0.45 Pg (Fang et al., 2001).

Apart from vegetation $C$ stock, afforestation also influences the soil C stock. Approximately $75 \%$ of the total terrestrial C is stored in the world's soils, and forest soils hold approximately $40 \%$ of all

\footnotetext{
* Corresponding authors.

E-mail addresses: wanghm@igsnrr.ac.cn (H. Wang), fuxl@igsnrr.ac.cn (X. Fu).
}

belowground C (Dixon et al., 1994; Huntington and Center, 1995). Therefore, even a small disturbance of the soil may result in a significant effect on the global C budget (Paul et al., 2002). Following afforestation, an initial decrease in soil $\mathrm{C}$ stock has been commonly observed (Trouvé et al., 1994; Paul et al., 2002, 2003) and a new soil $C$ equilibrium is eventually reached after several years (Guo and Gifford, 2002). In recent years, a process-based model and a meta-analysis indicated that soil $\mathrm{C}$ stock decreased after afforestation, reached the minimum value after $5-10$ years, and then recovered to pre-disturbance levels after approximately 20 years (Huang et al., 2007; Li et al., 2012). One possible reason was that the new $\mathrm{C}$ input from the young stands was too low to match the C decomposition (Vesterdal et al., 2002), and the plants-derived fresh organic matter (litter, root exudates, etc.) input may accelerate soil organic matter (SOM) decomposition due to the rhizosphere priming effects (Dijkstra et al., 2006). Another possible reason was the increase of soil $C$ release caused by site preparation, because it can disturb soil structure, modify 
microclimate and enhance aeration (La Scala et al., 2005; Mallik and $\mathrm{Hu}, 1997)$. However, most researches did not investigate the effects of site preparation without plants on soil $C$ release.

Site preparation is typical site treatment before afforestation to favor the survival and growth of planted trees by reducing competition from understory vegetation (Karlsson, 2002). Site preparation generally includes site clearing (brush clearing and controlled burning) and soil preparation (overall soil preparation, spot soil preparation and no soil reparation). The effect of controlled burning on soil $\mathrm{C}$ release is more complex than that of brush clearing. Compared to brush clearing, controlled burning can affect soil $\mathrm{C}$ release not only during the burning process but also during the post-burning period (Fernández et al., 1999). During the burning process, $60-80 \%$ of the surface organic materials are burned out and revert to the atmosphere as $\mathrm{CO}_{2}$ (González-Pérez et al., 2004), leading to a remarkable decrease in soil C stock (Guo et al., 2006). The long-term impact of burning on the ecosystem-atmosphere $C$ exchange has been reported, however, these results were inconsistent (Phillips et al., 2002; Wuthrich et al., 2002; Hubbard et al., 2004; Ma et al., 2004). These contradictory results may be attributed to the difference of the burning intensity, soil microclimate, topography, and vegetation (McCarthy and Brown, 2006). During the burning, the burning intensity determines the amount of ash (Certini, 2005), soil properties (Boerner et al., 2000), soil microbial and root mortality (Chapin et al., 2004). In addition, ash deposition can increase the soil respiration $\left(R_{\mathrm{S}}\right)$ through increased nutrient release and hence available $C$ substrate for microbes (Fritze et al., 1994), whereas alterations in soil chemistry can reduce microbial activity (Pietikäinen and Fritze, 1995; Badía and Martí, 2003). However, the relative importance of each of these components of burning on $R_{\mathrm{S}}$ is largely unknown.

Soil preparation, such as ploughing, ripping or disking, enhances soil C release (Post and Kwon, 2000; McLaughlin et al., 2000; Bernoux et al., 2006) by several mechanisms. Soil preparation mixed the organic surface layer with mineral soil, which created new conditions for organisms and may enhanced the decomposition rates of the buried organic matter (Johansson, 1994). In addition, soil preparation could disrupt soil aggregates and transfer labile organic matter to soil microorganisms (La Scala et al., 2008), resulting in a reduction in the amounts of intra-aggregate soil organic C. Soil preparation also affects soil C release by modifying the soil surface microclimate, e.g., the soil water content and temperature (Mallik and Hu, 1997). Enhanced $R_{\mathrm{S}}$ after soil preparation has been demonstrated (La Scala et al., 2005; Mallik and Hu, 1997), but the effects varied with on soil texture, initial soil C stocks and climate (Post and Kwon, 2000; Six et al., 2002). However, few studies have assessed the soil preparation effects on $R_{\mathrm{S}}$ in subtropical soils (Feller and Beare, 1997). Compared with the overall soil preparation, spot soil preparation affects the soil microclimate and properties with a relatively lower intensity. However, few studies have assessed the effects of spot soil preparation on $R_{\mathrm{S}}$ (Pumpanden et al., 2004; Strömgren and Mjöfors, 2012).

In subtropical China, forests encompass a total area of approximately 53 million hectares, of which approximately $41 \%$ are young plantations. Brush clearing, controlled burning and soil preparation before planting are traditional silvicultural practices to improve the survival rate and growth in South China (Yang et al., 2005). However, these measures can cause substantial loss and redistribution of organic matter (Johnson and Curtis, 2001; Certini, 2005). Furthermore, subtropical forests are characterized by the East Asian monsoon climate with a clear wet season and dry season and approximately $60 \%$ of precipitation occurred during the short rainy season from March to June (Wang et al., 2012a). Such higher rainfall, not only advantaged of moister soil for decomposition (Post et al., 1982), but also accelerated the soil surface compaction because of the rain splash (Mataix-Solera et al., 2011), and then may influence the duration of soil preparation on $R_{\mathrm{S}}$. However, there is very little information available regarding the effect of site preparation on soil $C$ release in this area (Guo et al., 2010). Especially, with climate-change-induced changes in precipitation amount and patterns, we need a better understanding to the impacts of site preparation on soil $\mathrm{C}$ release in subtropical China.

The main objectives of the present study were to assess the effects of different site preparation treatments before afforestation on soil C release. Based on previously documented $R_{\mathrm{S}}$ after similar site preparation (Guo et al., 2010; Mallik and Hu, 1997) and soil C stock change after afforestation in the same area (Huang et al., 2007), we hypothesize that (1) compared with brush clearing, controlled burning would decrease the annual cumulative $R_{\mathrm{S}}$ because litter and organic carbon are consumed in burning; (2) overall soil preparation increases the annual cumulative $R_{\mathrm{S}}$, but spot soil preparation has less effects on the annual cumulative $R_{\mathrm{S}}$ due to the small disturbance area; and (3) site preparation effects on $R_{\mathrm{S}}$ may decline gradually over time, because of its direct effect on soil physical property might be weakened and lack of fresh organic matter input.

\section{Materials and methods}

\subsection{Experimental site}

The experiment was carried out at the Qianyanzhou Ecological Research Station $\left(26^{\circ} 44^{\prime} 39^{\prime \prime} \mathrm{N}, 115^{\circ} 03^{\prime} 33^{\prime \prime} \mathrm{E}\right)$ in subtropical China. The site is controlled by a warm and humid monsoon climate and is characterized by a clear summer drought due to the unevenly distributed rainfall. The annual mean air temperature was $17.9^{\circ} \mathrm{C}$, and the precipitation was $1469 \mathrm{~mm} \mathrm{yr}^{-1}$ from 1985 to 2008 (Wang et al., 2011). The soil was iron-rich red soil and classified as Typic Dystrudepts Udepts Inceptisols according to U.S. soil taxonomy (Wang et al., 2013). This study was conducted in an abandoned orange orchard. The vegetation was predominated by Loropetalum chinensis ( $\mathrm{R}$. Br.) Oliv, Cogon grass (Imperata cylindrica (L.) Beauv.) and Canadian Fleabane (Conyza canadensis (L.) Cronq.).

\subsection{Experimental design}

The experiment used a paired, nested design with site clearing (brush clearing and controlled burning) as primary treatments and soil preparation (overall soil preparation, spot soil preparation and no soil preparation) as secondary treatments. Three blocks of $14 \mathrm{~m} \times 9 \mathrm{~m}$ were established for brush clearing and controlled burning treatments. Each block was placed about $1 \mathrm{~m}$ apart and was divided into six $4 \mathrm{~m} \times 4 \mathrm{~m}$ subplots (Fig. 1). In two subplots of each block, sites were fully ploughed (brush clearing + overall soil preparation, BCOP; controlled burning + overall soil preparation, CBOP) with a depth of $30 \mathrm{~cm}$ or patch scarified (brush clearing + spot soil preparation, BCSP; and controlled burning + spot soil preparation, (BSP) with a size of $50 \times 50 \times 40 \mathrm{~cm}^{3}$ (Length $\times$ Width $\times$ Depth). The two remaining subplots acted as no soil preparation controls (brush clearing control, BCCT; controlled burning control, CBCT). Further descriptions of site preparation were listed in Table 1.

\subsection{Measurement of soil basal respiration}

After site preparation, polyvinyl chloride (PVC) collars $(11 \mathrm{~cm}$ in diameter, $6 \mathrm{~cm}$ in height) were immediately placed. In each subplot for BCCT, BCOP, CBCT and CBOP, four PVC collars were pressed 


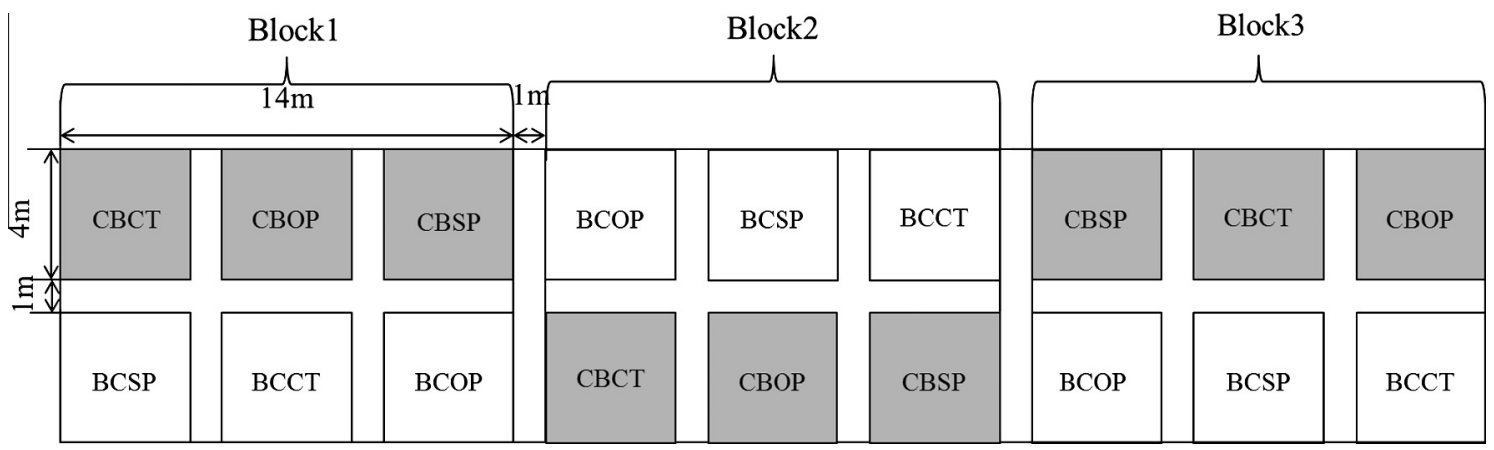

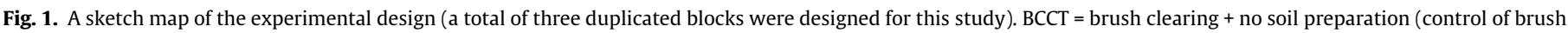

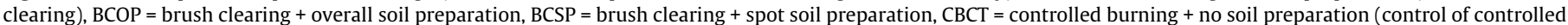
burning), $\mathrm{CBOP}=$ controlled burning + overall soil preparation, $\mathrm{CBSP}=$ controlled burning + spot soil preparation.

Table 1

Summary of site preparation treatments applied at Qianyanzhou (LFH = Litter, Fermentation and Humus subhorizons).

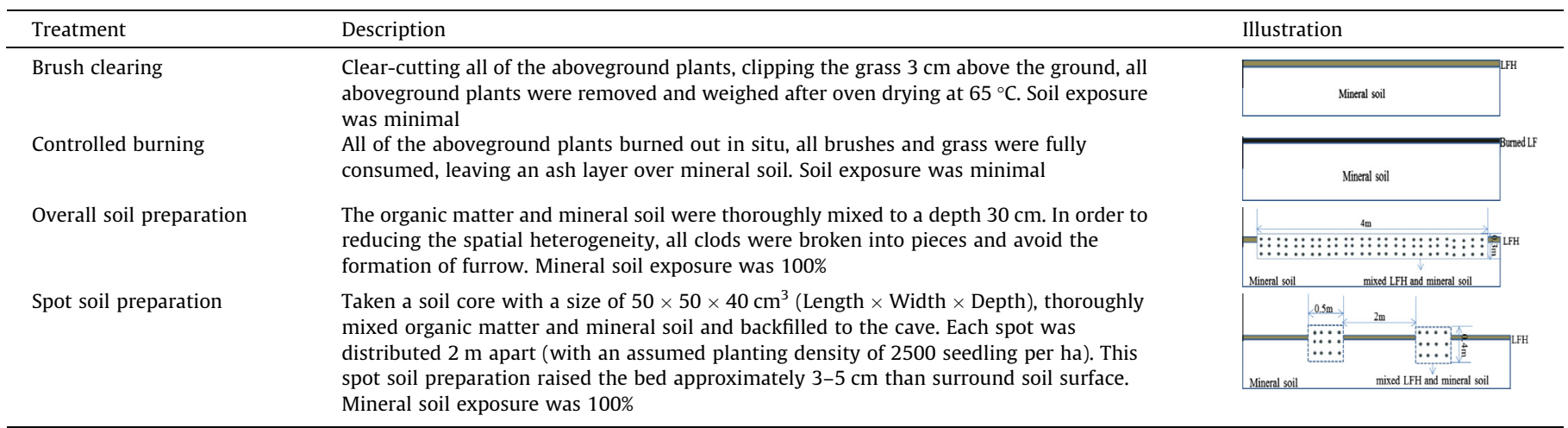

into the soil at randomly selected positions (approximately $2 \mathrm{~m}$ apart). In each BCSP or CBSP subplot, six PVC collars were inserted into soil. Three PVC collars were inserted in spot, one of them was inserted in the center of spot, and others were inserted around approximately $10 \mathrm{~cm}$. The other three collars were in the nonspot place at randomly selected positions. Soil collars were inserted at $3 \mathrm{~cm}$ depth carefully to avoid disturbing soil, and the soil around the collars was pressed slightly to avoid air leakage and the underestimation of the $R_{\mathrm{S}}$.

The $R_{\mathrm{S}}$ was measured from March 2011 to March 2013 in different frequencies as follows: once daily during the first week after site preparation, every other day in the following month, and weekly from the second month after site preparation to the end. The LI-8100 portable soil $\mathrm{CO}_{2}$ flux system (Li-Cor, Inc., Lincoln, NE, USA) was used to measure the $R_{\mathrm{S}}$. We used a $10 \mathrm{~cm}$ respiration chamber, in which the increase in $\mathrm{CO}_{2}$ concentration was recorded at $1 \mathrm{~s}$ intervals by the LI-8100's infrared gas analyser. The length of measurement was limited to $2 \mathrm{~min}$, in order to avoid important chamber $\mathrm{CO}_{2}$ concentration changes (Davidson et al., 2002). All measurements were made between 9:00 and 11:00 am, because the $R_{\mathrm{S}}$ measured in this time were close to daily means (Wang et al., 2012a). At least 2 days before each measurement the living plants insides the soil collars were removed by hand to eliminate aboveground plant respiration.

\subsection{Measurement of soil properties}

The soil temperature $\left(T_{\mathrm{S}}\right)$ and soil water content (SWC) at $10 \mathrm{~cm}$ below soil surface were monitored at each chamber. $T_{\mathrm{S}}$ was measured using a portable temperature probes (JM624 digital thermometer, Living-Jinming Ltd., China). Volumetric soil moisture $\left(\mathrm{m}^{3} \mathrm{~m}^{-3}\right)$ was measured using a moisture probe meter (TDR100, Spectrum, USA). In block 2, continuous measurements of the $T_{\mathrm{S}}$ and SWC were taken every 30-min using thermocouples (ST-100, Campbell Inc.) and TDR sensors (CS616, Campbell Inc.) at $10 \mathrm{~cm}$ depth. These data were then used to estimate cumulative $R_{\mathrm{S}}$.

Soil was collected before and after ( 7 days) site preparation, we used a 45-mm-diameter hand auger to take soil samples at depths of $0-10 \mathrm{~cm}$ and $10-20 \mathrm{~cm}$. Three soil cores were taken and combined into a composite soil samples in each plot. Soil samples were divided into two parts, one part was air-dried and used for soil chemical analyses and the other was used to assess the microbial biomass $C$. At each sampling location, soil bulk density was determined by use of the high stainless steel cutting ring core with a $5 \mathrm{~cm}$ diameter and $5 \mathrm{~cm}$ at the depth of $0-10 \mathrm{~cm}$ and $10-20 \mathrm{~cm}$, soil samples in the rings were dried in the laboratory at $105^{\circ} \mathrm{C}$ for $48 \mathrm{~h}$ for calculating soil bulk density.

Soil samples used to measure soil organic carbon (SOC), total nitrogen (TN) and $\mathrm{pH}$ were passed through a $0.25 \mathrm{~mm}$ sieve and then measured with a CN-element analyzer (Elementar VarioMax $\mathrm{CN}$, Mt. Laurel, NJ). The soil $\mathrm{pH}$ was measured potentiometrically in a 1: 2.5 soil: water suspension. Samples for microbial biomass $C$ analysis were sieved $(2 \mathrm{~mm})$ and estimated by chloroform fumigation-extraction (Vance et al., 1987).

\subsection{Statistical analysis}

An exponential equation (Eq. (1)) was used to simulate the relationship between the $T_{\mathrm{S}}$ and $R_{\mathrm{S}}$ rate. To understand the dependence of the $R_{\mathrm{S}}$ rate on SWC, all of the observed $R_{\mathrm{S}}$ rates were normalized to $15^{\circ} \mathrm{C}\left(R_{\mathrm{S}, 15}\right)$ using Eq. (2). The relationship between $R_{\mathrm{S}, 15}$ and SWC was determined with Eq. (3). Eq. (4) was used to model the 
responses of the $R_{\mathrm{S}}$ rate to both $T_{\mathrm{S}}$ and SWC (Xu and Qi, 2001). The annual mean and monthly mean $R_{\mathrm{S}}$ rates were the weighted averages of the observed $R_{\mathrm{S}}$ rate. The annual cumulative $R_{\mathrm{S}}$ was extrapolated with fitted models as generated by Eq. (4) and the continuous $T_{\mathrm{S}}$ and SWC datasets (Wang et al., 2012a). Eq. (5) was used to calculate the annual cumulative $R_{\mathrm{S}}$ of spot soil preparation, which was the sum of the $R_{\mathrm{S}}$ of 2500 spots (the planting density was assumed to be 2500 trees ha ${ }^{-2}$ ) and no-spot area.

$R_{\mathrm{S}}=a * e^{b T s}$

$R_{\mathrm{S}, 15}=R_{\mathrm{S}} * e^{b(15-T S)}$

$R_{\mathrm{S}, 15}=a * S W C^{b}$

$R_{\mathrm{S}}=a * e^{b T_{S}} * S W C^{c}$

$\sum R_{\mathrm{S}}=\sum R_{\mathrm{s}(\mathrm{spot})}+\sum R_{\mathrm{s}(\mathrm{no}-\mathrm{spot})}$

where $R_{\mathrm{S}}$ is the soil basal respiration $\left(\mu \mathrm{mol} \mathrm{m} \mathrm{m}^{-2} \mathrm{~s}^{-1}\right.$ ), $R_{\mathrm{S}, 15}$ is the normalized soil basal respiration at a reference temperature of $15{ }^{\circ} \mathrm{C}(283.15 \mathrm{~K}), T_{\mathrm{S}}$ is the soil temperature $\left({ }^{\circ} \mathrm{C}\right)$, and SWC is the volumetric soil water content $\left(\mathrm{cm}^{3} \mathrm{~cm}^{-3}\right) . a, b$ and $c$ are the fitted parameters.

The main and interactive effects of site clearing and soil preparation treatments on $R_{\mathrm{S}}, T_{\mathrm{S}}$ and SWC were determined with repeated measures analysis of variance (RM-ANOVA). Between subject effects were evaluated as treatments and within subject effects were time-of-month. A General Linear Model (GLM) with a least significant difference (LSD) test was used to examine the effects of soil preparation on the monthly mean values within the brush clearing and controlled burning. Regression analyses were used to test the associations among $R_{\mathrm{S}}, T_{\mathrm{S}}$ and SWC. To examine which variable had a more important effect $R_{\mathrm{S}}$, simple and multiple nonlinear regression analyses were applied between $R_{\mathrm{S}}$ and these measured variables under the different site preparation treatments. SPSS software (SPSS 16, SPSS Inc., Illinois, Chicago, USA) was used to perform all analyses. The standard 0.05 level was used throughout as a cutoff for statistical significance.

\section{Results}

\subsection{Soil physicochemical properties}

Compared with brush clearing (control), controlled burning (control) significantly decreased soil total nitrogen (TN) by $15.4 \%$ in 10-20 cm depth $(P<0.05)$, but significantly increased microbial biomass $C$ by $28.0 \%$ in $0-10 \mathrm{~cm}$ depth $(P<0.05)$. No other distinguished differences were detected in soil physicochemical properties between brush clearing and controlled burning. Soil preparation significantly affected soil physicochemical properties. Within brush clearing plots, BCOP significantly decreased soil organic $C$ (SOC) and TN in $0-10 \mathrm{~cm}$ depth and significantly decreased microbial biomass $C$ and soil bulk density in two depths compared with BCCT. BCSP significantly decreased bulk density in two depths, but no significant difference in SOC, TN and microbial biomass $\mathrm{C}$ were found at any of the soil depths, compared to BCCT (Table 2). In the controlled burning plots, CBOP significantly decreased SOC, TN and microbial biomass $C$ in $0-10 \mathrm{~cm}$ depth, and significantly decreased bulk density in all the depths compared to CBCT. CBSP significantly decreased bulk density in two depths compared with CBCT.

\subsection{Soil microclimate}

The $T_{\mathrm{S}}$ exhibited a similar seasonal variation trend and peaked in July and August in all treatments (Fig. 2). No distinguished difference in $T_{\mathrm{S}}$ was detected at all treatments (Table 3). SWC

Table 2

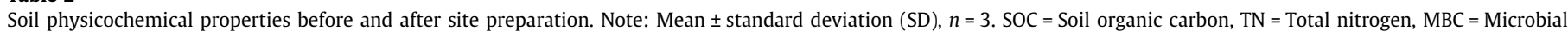
biomass carbon, BD = Soil bulk density.

\begin{tabular}{|c|c|c|c|c|c|}
\hline Depth $(\mathrm{cm})$ & Treatments & $\mathrm{SOC}\left(\mathrm{g} \mathrm{kg}^{-1}\right)$ & $\mathrm{TN}\left(\mathrm{g} \mathrm{kg}^{-1}\right)$ & $\mathrm{MBC}\left(\mathrm{mg} \mathrm{kg}^{-1}\right)$ & $\mathrm{BD}\left(\mathrm{g} \mathrm{cm}^{-3}\right)$ \\
\hline $0-10$ & Before site preparation & $13.02 \pm 0.16$ & $1.33 \pm 0.02$ & $113.38 \pm 10.55$ & $1.41 \pm 0.01$ \\
\hline $10-20$ & & $7.89 \pm 0.21$ & $0.85 \pm 0.01$ & $40.73 \pm 6.34$ & $1.40 \pm 0.01$ \\
\hline \multicolumn{6}{|c|}{7 days after site preparation } \\
\hline \multirow[t]{6}{*}{$0-10$} & BCCT & $15.14 \pm 1.27 a$ & $1.39 \pm 0.10 \mathrm{a}$ & $74.84 \pm 3.27 b$ & $1.40 \pm 0.02 a$ \\
\hline & BCOP & $8.37 \pm 2.40 \mathrm{~b}$ & $0.92 \pm 0.18 b$ & $64.03 \pm 9.25 b$ & $1.18 \pm 0.04 b$ \\
\hline & BCSP & $13.11 \pm 2.25 a$ & $1.26 \pm 0.20 \mathrm{ab}$ & $119.01 \pm 10.06 a$ & $1.18 \pm 0.02 b$ \\
\hline & $\mathrm{CBCT}$ & $14.42 \pm 5.05 a$ & $1.23 \pm 0.44 a$ & $95.86 \pm 8.72 \mathrm{a}$ & $1.43 \pm 0.02 a$ \\
\hline & CBOP & $6.75 \pm 0.95 b$ & $0.78 \pm 0.11 b$ & $36.23 \pm 7.95 b$ & $1.04 \pm 0.05 b$ \\
\hline & CBSP & $13.34 \pm 0.52 \mathrm{a}$ & $1.21 \pm 0.12 \mathrm{a}$ & $88.34 \pm 14.33 a$ & $1.01 \pm 0.12 b$ \\
\hline \multirow[t]{6}{*}{$10-20$} & ВCСТ & $9.84 \pm 2.00 \mathrm{a}$ & $0.97 \pm 0.08 \mathrm{a}$ & $34.19 \pm 10.50 \mathrm{ab}$ & $1.38 \pm 0.01 a$ \\
\hline & BCOP & $9.14 \pm 1.48 \mathrm{a}$ & $0.96 \pm 0.08 a$ & $26.82 \pm 3.14 b$ & $1.13 \pm 0.04 b$ \\
\hline & BCSP & $10.67 \pm 1.84 \mathrm{a}$ & $1.07 \pm 0.16 a$ & $50.87 \pm 13.82 a$ & $1.18 \pm 0.05 b$ \\
\hline & CBCT & $8.63 \pm 3.30 \mathrm{a}$ & $0.82 \pm 0.34 a$ & $31.54 \pm 12.58 b$ & $1.39 \pm 0.03 a$ \\
\hline & CBOP & $7.80 \pm 1.83 a$ & $0.87 \pm 0.12 a$ & $48.51 \pm 16.93 \mathrm{ab}$ & $1.10 \pm 0.07 b$ \\
\hline & CBSP & $10.31 \pm 2.18 \mathrm{a}$ & $0.95 \pm 0.19 a$ & $64.82 \pm 11.63 a$ & $1.21 \pm 0.11 b$ \\
\hline \multicolumn{6}{|c|}{ Analysis of variance } \\
\hline \multicolumn{2}{|c|}{ Site clearing $(\mathrm{C})$} & ns & ${ }^{*}$ & ${ }^{* * * *}$ & $*$ \\
\hline \multicolumn{2}{|c|}{ Soil preparation $(\mathrm{P})$} & $* * * *$ & $* * *$ & $* * *$ & $* * *$ \\
\hline \multicolumn{2}{|c|}{ Depth (D) } & $* * * *$ & $* * *$ & $* * *$ & ns \\
\hline \multicolumn{2}{|l|}{$\mathrm{C} \times \mathrm{P}$} & ns & ns & ns & ns \\
\hline \multicolumn{2}{|l|}{$\mathrm{C} \times \mathrm{D}$} & ns & ns & ${ }^{* *}$ & * \\
\hline \multicolumn{2}{|l|}{$\mathrm{P} \times \mathrm{D}$} & $* * *$ & ${ }^{* * *}$ & $* * *$ & * \\
\hline \multicolumn{2}{|l|}{$\mathrm{C} \times \mathrm{P} \times \mathrm{D}$} & ns & ns & $* *$ & ns \\
\hline
\end{tabular}

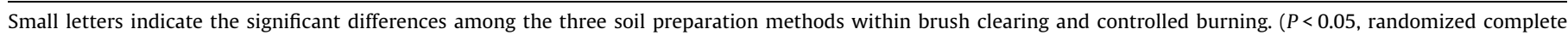
block design ANOVA followed by multiple comparison tests). ns indicates not significant.

* Significant at the 0.05 probability level.

** Significant at the 0.01 probability level.

*** Significant at the 0.001 probability level. 


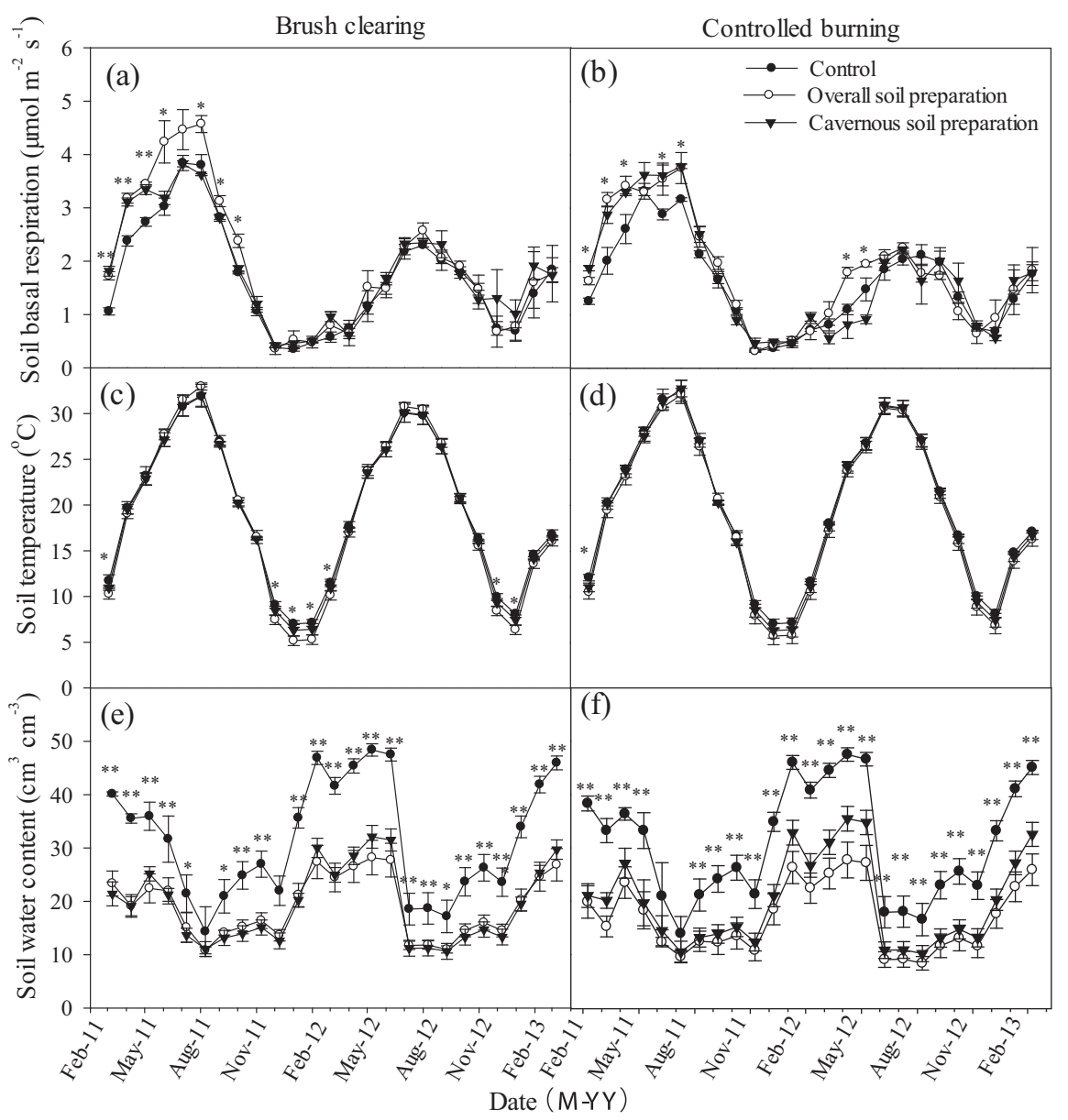

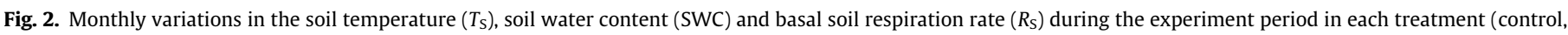

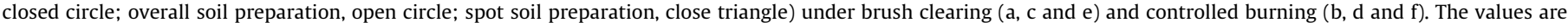
mean $\pm \mathrm{SD},(n=3)$. $^{*}$ and ${ }^{* *}$ are statistically significantly different among three levels soil preparation treatments at $P<0.05$ and 0.01 , respectively.

experienced a reversed trend, which in the wet season was higher than that in the dry season. There was no significant difference in SWC between BCCT and CBCT, over the two years experiment period. However, soil preparation significantly decreased SWC. Within brush clearing plots, the mean SWC decreased by $39.2 \%$ and $38.8 \%$ for the BCOP and BCSP across the two years experiment period, respectively, compared to the BCCT. Within controlled burning plots, a significant reduction was observed in SWC for both CBOP and CBSP by $45.0 \%$ and $35.0 \%$ (Table 3 ) compared with CBCT, respectively.

\subsection{The response of basal soil respiration to site preparation}

All site preparation treatments showed a strong seasonal pattern of $R_{\mathrm{S}}$ with maximum rates from June to August (Fig. 2). Compared with brush clearing (control), controlled burning (control) significantly decreased monthly mean $R_{\mathrm{S}}$ rate from July to September in the first year. However, no significant difference in the $R_{\mathrm{S}}$ rate was found between the two treatments in the second year. The annual cumulative $R_{\mathrm{S}}$ was also calculated and found that controlled burning significantly decreased the annual cumulative $R_{\mathrm{S}}$ by $12.4 \%(P<0.05)$ compared to the brush clearing in the first year. In the second year, however, no significant decrease in the annual cumulative $R_{\mathrm{S}}$ for the controlled burning treatment was detected.

In the brush clearing plots, compared with BCCT, BCOP significantly increased the monthly mean $R_{\mathrm{S}}$ rate during the first eight months (Fig. 2a), thereby increasing the annual mean $R_{\mathrm{S}}$ rate by
25.3\% $(P<0.05)$ and annual cumulative $R_{\mathrm{S}}$ increased by $23.9 \%$ $(P<0.05)$ in the first year, but there was no obvious difference during the second year (Fig. 3). For BCSP, the monthly mean $R_{\mathrm{S}}$ rate also significantly increased compared to the BCCT in the first three months after site preparation (Fig. 2a), but no significant enhancement was detected in the annual mean $R_{\mathrm{S}}$ rate and cumulative $R_{\mathrm{S}}$ over the two years (Fig. 3).

In the controlled burning plots, compared with CBCT, the monthly mean $R_{\mathrm{S}}$ rate of CBOP and CBSP significantly increased within the first six months, except for a small disturbance (Fig. 2b). For the first year, CBOP and CBSP significantly increased the annual mean $R_{\mathrm{S}}$ rate by $20.0 \%$ and $21.0 \%(P<0.05)$, compared CBCT, respectively. The annual cumulative $R_{\mathrm{S}}$ significantly increased by $19.7 \%(P<0.05)$ for CBOP, but no obvious changes were observed for CBSP (Fig. 3). During the second year, however, there was no significant difference in the monthly or annual mean $R_{\mathrm{S}}$ rate among the three treatments.

\subsection{The dependence of soil respiration on soil temperature and soil water content}

The relationship between $T_{\mathrm{S}}$ and $R_{\mathrm{S}}$ rate for each treatment was fitted with an exponential model over the two years experiment period and results are given in Table $4 . T_{\mathrm{S}}$ explained more than $40 \%$ of $R_{\mathrm{S}}$ variation (Table 4). Unlike the relationship between $R_{\mathrm{S}}$ and $T_{\mathrm{S}}, R_{\mathrm{S}, 15}$ and SWC had no significant relationship over the two years experiment period (Table 4). However, when the 
Table 3

Annual mean soil temperature $\left(T_{\mathrm{S}}\right)$, soil water content (SWC) and soil respiration $\left(R_{\mathrm{S}}\right)$ influenced by site preparation treatments at Qianyanzhou Ecological Reaearch Station in subtropical China (mean $\pm \mathrm{SD}, n=3$ ).

\begin{tabular}{|c|c|c|c|c|c|c|}
\hline Time/Treatments & $T_{\mathrm{S}}$ & & SWC & & $R_{\mathrm{S}}$ & \\
\hline \multicolumn{7}{|l|}{ 1st year } \\
\hline ВССТ & $19.29 a$ & 0.58 & 29.70a & 2.27 & $1.98 \mathrm{~b}$ & 0.09 \\
\hline BCOP & $18.84 a$ & 0.45 & $18.40 \mathrm{~b}$ & 1.84 & $2.47 \mathrm{a}$ & 0.20 \\
\hline BCSP & $18.98 \mathrm{a}$ & 0.29 & $18.06 \mathrm{~b}$ & 1.12 & $2.18 b$ & 0.02 \\
\hline СВCT & $19.65 a$ & 0.24 & $29.15 a$ & 2.53 & $1.77 \mathrm{~b}$ & 0.06 \\
\hline CBOP & $18.90 \mathrm{a}$ & 0.55 & $16.06 \mathrm{~b}$ & 1.94 & $2.14 \mathrm{a}$ & 0.10 \\
\hline CBSP & $19.27 \mathrm{a}$ & 0.37 & $18.46 \mathrm{~b}$ & 2.06 & $2.13 a$ & 0.07 \\
\hline \multicolumn{7}{|l|}{ 2nd year } \\
\hline $\mathrm{BCCT}$ & $19.56 a$ & 0.54 & $32.23 a$ & 2.13 & $1.39 a$ & 0.14 \\
\hline BCOP & 19.16a & 0.48 & 19.30b & 1.91 & $1.48 \mathrm{a}$ & 0.28 \\
\hline BCSP & $19.34 a$ & 0.37 & $19.71 b$ & 1.18 & $1.49 \mathrm{a}$ & 0.11 \\
\hline $\mathrm{CBCT}$ & $20.05 a$ & 0.29 & $31.48 a$ & 2.00 & $1.35 \mathrm{a}$ & 0.15 \\
\hline CBOP & $19.34 a$ & 0.69 & $17.15 b$ & 2.08 & $1.45 a$ & 0.23 \\
\hline CBSP & $19.76 a$ & 0.47 & $20.69 b$ & 1.90 & $1.32 \mathrm{a}$ & 0.10 \\
\hline
\end{tabular}

Analysis of variance

1st year

Site clearing $(\mathrm{C})$

Soil preparation $(\mathrm{P}) \quad \mathrm{ns}$

$\mathrm{C} \times \mathrm{P}$

ns

ns

ns

ns

****

2nd year

C

$\mathrm{C} \times \mathrm{P}$

ns
ns
ns

nS

ns

ns

ns

Different letters on means indicates significant difference at $P<0.05$ between soil preparation treatments within brush clearing and controlled burning treatments. ns indicates not significant.

*Significant at the 0.05 probability level.

** Significant at the 0.01 probability level.

**** Significant at the 0.001 probability level.

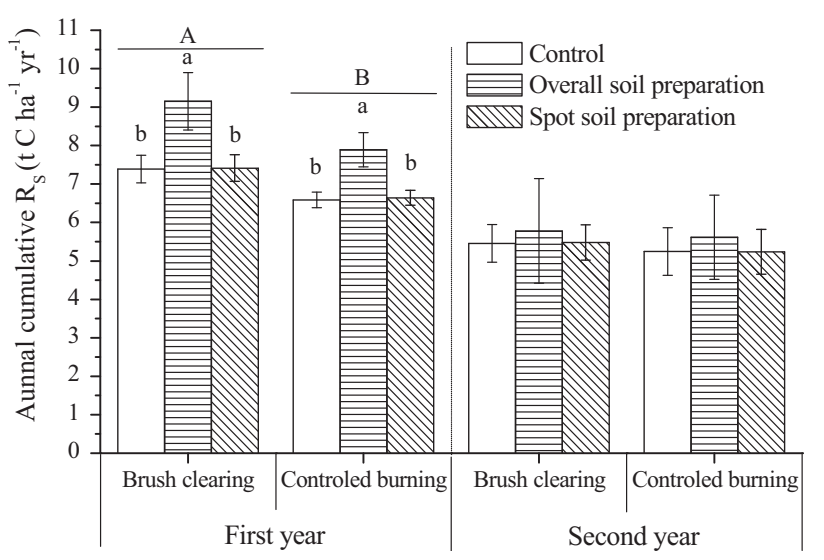

Fig. 3. Annual cumulative $R_{\mathrm{S}}$ (mean $\pm \mathrm{SD}, n=3$ ) in control, overall and spot soil preparation in brush clearing and controlled burning plots. Different small and capital letters indicate the significant differences among three levels of soil preparation and between two site clearing treatments, respectively.

observation period was separated into dry and wet seasons, significant relationships between $R_{\mathrm{S}, 15}$ and SWC were detected (Table 4). Although the relationships between $R_{\mathrm{S}, 15}$ and SWC were weaker than those between $R_{\mathrm{S}}$ and $T_{\mathrm{S}}$, they were significant $(P<0.05)$, explaining $11-23 \%$ of $R_{\mathrm{S}}$ variations (Table 4 ). We combined $T_{\mathrm{S}}$ and SWC to examine the interactive effects of these factors on $R_{\mathrm{S}}$ by Eq. (4). The results indicate that $T_{\mathrm{S}}$ and SWC together contributed 39-60\% (two years) of the variation in $R_{\mathrm{S}}$.

Compared to brush clearing (control), controlled burning (control) had no significantly effect on the relationship between $R_{\mathrm{S}}$ and $T_{\mathrm{S}}$, as well as the interactive effects of $T_{\mathrm{S}}$ and SWC on $R_{\mathrm{S}}$. However, soil preparation significantly weakened these relationships. In the brush clearing treatments, the correlation of seasonal $R_{\mathrm{S}}$ with $T_{\mathrm{S}}$ was best in BCCT $\left(R^{2}=0.62, P<0.05\right)$, followed by BCOP $\left(R^{2}=0.49, P<0.05\right)$ and BCSP $\left(R^{2}=0.47, P<0.05\right)$. The $T_{\mathrm{S}}$ and SWC together explained $48 \%$ and $43 \%$ of the variation in $R_{\mathrm{S}}$ rate during the two years for BCOP and BCSP, respectively. In the controlled burning plots, we found that $T_{\mathrm{S}}$ explained $46 \%$ and $42 \%$ variation of $R_{\mathrm{S}}$ in CBOP and CBSP, respectively, which is lower than that in CBCT (58\%). $T_{S}$ and SWC together explained $45 \%$ and $39 \%$ of the variation in the $R_{\mathrm{S}}$ rate for CBOP and CBSP, respectively (Table 4).

\section{Discussion}

\subsection{Effect of controlled burning on soil C release}

Controlled burning significantly decreased the annual cumulative $R_{\mathrm{S}}$ by $12.4 \%$ (Fig. 3 ) compared with brush clearing in the first year. These results support our first hypothesis. Decreases in $R_{\mathrm{S}}$ after controlled burning have also been found by other studies (Guo et al., 2010; Pietikäinen and Fritze, 1995). Based on a mateanalysis of burning experimental data on globe, Wang et al. (2012b) concluded that burning significantly decreased $R_{\mathrm{S}}$ by $13.5 \%$. These results may be explained by several factors. First, controlled burning induced a decrease in soil organic matter by rapid oxidation (Guo et al., 2006). Organic carbon may losses higher than 50\% under pine forest after a burning (Fernández et al., 1997). In addition, the burning may change the quality of SOC (Certini, 2005). González-Pérez et al. (2004) believed that burning led to soil humus transformed into a new particulate $\mathrm{C}$ forms highly resistant to oxidation and biological degradation. In our study, the SOC decreased by $6 \%$ for the controlled burning treatments compared to brush clearing (Table 1 ). Therefore, the decreased $R_{\mathrm{S}}$ could be due to the reduction of soil $C$ substrate in the controlled burning treatment. Second, compared to brush clearing, controlled burning may change the soil microclimate. Treseder et al. (2004) found that after burning $T_{\mathrm{S}}$ changes temporarily because of the disappearing of the litter mantle and the darkening of ground. In addition, burning can yield hydrophobic hydrocarbons that, together with the layer of ashes, could limit the soil's water infiltration capacity and hence its moisture content (Neary et al., 1999). Third, controlled burning may affect soil aeration. Because of burning may deteriorate soil structure by affecting aggregate stability and soil sealing can occur as a result of aggregate breakdown by the rain splash (Mataix-Solera et al., 2011). Moreover, soil pores were reported to be blocked by burning ashes (Neary et al., 1999; Martin and Moody, 2001). In our study site, there is abundant precipitation, which may lead to the breakdown of soil aggregates and redistribution of ashes to block the macro-pores (Lavee et al., 1995). Therefore, decreases in $R_{\mathrm{S}}$ could be due to decreased soil aeration in the controlled burning treatment. Last, controlled burning can lead to a significant reduction in microbial biomass C (Pietikäinen and Fritze, 1995). This decline in microbial biomass $C$ after controlled burning has either a direct effect or indirect effect on decreasing the soil moisture content, destroying soil structure or increasing soil pH (Fritze et al., 1994). However, in our study, microbial biomass C did not change with the controlled burning compare to the brush clearing. Hamman et al. (2007) observed that microbial biomass C did not change with burning, but there was a shift in soil microbial community structure. Sun et al. (2011) observed the soil microbial community structure by total phospholipid fatty acids (PLFAs), and found that the ratios of fungi PLFAs to bacteria PLFAs were low in the burned plots. This result suggests that only measurement on microbial biomass $C$ could not discover the effect on burning and merit further investigation.

Though controlled burning diminished cumulative $R_{\mathrm{S}}$ in the first year, the released $\mathrm{CO}_{2}$ from the above ground plants burning must be considered. The $C$ release of biomass burning in the experiment 
Table 4

Models for the relationship between the soil respiration $\left(R_{\mathrm{S}}\right)$, soil temperature $\left(T_{\mathrm{S}}\right)$ in ${ }^{\circ} \mathrm{C}$ and soil water content $\left(\mathrm{SWC}, \mathrm{cm}^{3} \mathrm{~cm}^{-3}\right)$.

\begin{tabular}{|c|c|c|c|c|c|c|c|c|c|c|c|c|c|c|}
\hline \multirow[t]{2}{*}{ Treatment } & \multirow[t]{2}{*}{ Period } & \multicolumn{4}{|c|}{$R_{\mathrm{S}}=a * e^{b T s}$} & \multicolumn{4}{|c|}{$R_{\mathrm{S}, 15}=a * S W C^{b}$} & \multicolumn{5}{|c|}{$R_{\mathrm{S}}=a * e^{b T_{S}} * S W C^{c}$} \\
\hline & & $a$ & $b$ & $R^{2}$ & $P$ & $a$ & $b$ & $R^{2}$ & $P$ & $a$ & $b$ & c & $R^{2}$ & $P$ \\
\hline \multirow[t]{3}{*}{ ВССТ } & Wet season & 0.46 & 0.07 & 0.53 & $<0.01$ & 11.26 & -0.61 & 0.23 & $<0.01$ & 5.86 & 0.05 & -0.62 & 0.67 & $<0.01$ \\
\hline & Dry season & 0.40 & 0.07 & 0.76 & $<0.01$ & 0.29 & 0.39 & 0.14 & $<0.01$ & 0.17 & 0.07 & 0.23 & 0.77 & $<0.01$ \\
\hline & Two years & 0.51 & 0.06 & 0.62 & $<0.01$ & 0.72 & 0.13 & 0.02 & 0.16 & 0.60 & 0.06 & -0.03 & 0.60 & $<0.01$ \\
\hline \multirow[t]{3}{*}{ BCOP } & Wet season & 0.80 & 0.05 & 0.44 & $<0.01$ & 8.70 & -0.51 & 0.11 & 0.01 & 4.78 & 0.05 & -0.54 & 0.50 & $<0.01$ \\
\hline & Dry season & 0.49 & 0.06 & 0.65 & $<0.01$ & 0.22 & 0.62 & 0.16 & $<0.01$ & 0.07 & 0.07 & 0.62 & 0.72 & $<0.01$ \\
\hline & Two years & 0.80 & 0.05 & 0.49 & $<0.01$ & 0.59 & 0.33 & 0.06 & 0.01 & 0.49 & 0.05 & 0.16 & 0.48 & $<0.01$ \\
\hline \multirow[t]{3}{*}{ BCSP } & Wet season & 0.81 & 0.05 & 0.38 & $<0.01$ & 7.79 & -0.50 & 0.18 & $<0.01$ & 6.64 & 0.05 & -0.65 & 0.55 & $<0.01$ \\
\hline & Dry season & 0.49 & 0.06 & 0.76 & $<0.01$ & 0.38 & 0.39 & 0.12 & 0.03 & 0.11 & 0.07 & 0.51 & 0.82 & $<0.01$ \\
\hline & Two years & 0.82 & 0.04 & 0.47 & $<0.01$ & 0.93 & 0.14 & 0.02 & 0.15 & 0.81 & 0.04 & 0.02 & 0.44 & $<0.01$ \\
\hline \multirow[t]{3}{*}{ СBCT } & Wet season & 0.42 & 0.07 & 0.58 & $<0.01$ & 11.19 & -0.63 & 0.17 & $<0.01$ & 5.65 & 0.06 & -0.69 & 0.66 & $<0.01$ \\
\hline & Dry season & 0.42 & 0.06 & 0.73 & $<0.01$ & 0.44 & 0.27 & 0.16 & $<0.01$ & 0.19 & 0.06 & 0.21 & 0.75 & $<0.01$ \\
\hline & Two years & 0.53 & 0.05 & 0.59 & $<0.01$ & 0.82 & 0.08 & 0.01 & 0.30 & 0.30 & 0.06 & 0.15 & 0.58 & $<0.01$ \\
\hline \multirow[t]{3}{*}{ CBOP } & Wet season & 0.78 & 0.05 & 0.47 & $<0.01$ & 4.92 & -0.34 & 0.14 & $<0.01$ & 2.54 & 0.05 & -0.35 & 0.55 & $<0.01$ \\
\hline & Dry season & 0.37 & 0.07 & 0.77 & $<0.01$ & 0.32 & 0.46 & 0.17 & $<0.01$ & 0.10 & 0.07 & 0.46 & 0.83 & $<0.01$ \\
\hline & Two years & 0.80 & 0.04 & 0.46 & $<0.01$ & 0.68 & 0.28 & 0.06 & 0.01 & 0.52 & 0.05 & 0.15 & 0.45 & $<0.01$ \\
\hline \multirow[t]{3}{*}{ CBSP } & Wet season & 0.83 & 0.05 & 0.32 & $<0.01$ & 5.55 & -0.38 & 0.11 & 0.01 & 3.50 & 0.04 & -0.42 & 0.39 & $<0.01$ \\
\hline & Dry season & 0.38 & 0.07 & 0.71 & $<0.01$ & 0.25 & 0.56 & 0.20 & $<0.01$ & 0.07 & 0.07 & 0.60 & 0.79 & $<0.01$ \\
\hline & Two years & 0.76 & 0.04 & 0.42 & $<0.01$ & 0.78 & 0.20 & 0.04 & 0.05 & 0.68 & 0.04 & 0.05 & 0.39 & $<0.01$ \\
\hline
\end{tabular}

was calculated by equation: $C=A \times B \times \alpha \times \beta$ (Seiler and Crutzen, 1980), where $C$ is $C$ release of biomass burning ( $C$ ha $\left.^{-1}\right), A$ is the total land area that was burned (ha), $B$ is the average aboveground biomass per unit area $\left(t \mathrm{tha}^{-1}\right), \alpha$ is the $\mathrm{C}$ concentration of the aboveground biomass (\%), and $\beta$ is the burning efficiency of the aboveground biomass (\%). In this experiment, $B$ was measured at brush clearing plots, as the biomass was relatively uniform among the plots. All of the aboveground plant in brush clearing plots were cut, removed and weighed after oven drying at $65^{\circ} \mathrm{C}$. $\alpha$ and $\beta$ are $45 \%$ and $90 \%$ according to Andreae (1991), respectively. The $C$ release of biomass burning was approximately $5.21 \pm 0.74 \mathrm{t} \mathrm{C} \mathrm{ha}^{-1}$ in this study. Therefore, compared with brush clearing, controlled burning significantly increased the annual soil $\mathrm{C}$ release by $57.8 \%$ in the first year. However, $C$ release of biomass burning in this study would be underestimated since the biomass calculation does not include the slash residues and the litters.

\subsection{Effect of overall and spot soil preparation on soil $C$ release}

Overall soil preparation increased the annual $R_{\mathrm{S}}$ compared with the control in the first year. These results support our second hypothesis. Both Mallik and Hu (1997) and Pumpanen (2003) reported that mixing organic matter with mineral soil significantly increased $R_{\mathrm{S}}$ rate. In detail, the organic matter decomposition rate was faster in buried sites than left on soil surface (Johansson, 1994; Lundmark-Thelin and Johansson, 1997). Lundmark-Thelin and Johansson (1997) found that burying needle litters and slash needle litters resulted in accelerated mass loss rates and increased nutrient availability as compared with litters decomposed on soil surface after three years. Accelerated decomposition rates are probably related to enhanced microbial activity and increased microbial population (Salonius, 1983), because soil mixing might improve substrate availability to soil microbial of deep soils (Thorburn et al., 2001) and habitat accessibility for the microbial in each layer. Furthermore, soil preparation may influence decomposition rate by modifying the soil microclimate, e.g., SWC and $T_{\mathrm{S}}$ (Mallik and Hu, 1997; Pérez-Batallón et al., 2001). By burying organic matter under mineral soil, SWC and $T_{\mathrm{S}}$ are like fluctuated less with depth, because having a buffering mineral layer above them creates a more stable environment (Bulmer et al., 1998). In our study, soil preparation significantly decreased SWC $(0-10 \mathrm{~cm})$. The relationship between the $R_{\mathrm{S}, 15}$ rate and SWC was positive in the dry season but negative in the wet season (Table 2). High SWC may inhibit the diffusion of $\mathrm{O}_{2}$ and impede the development of aerobic microorganisms, which can decrease $R_{\mathrm{S}}$ (Davidson et al., 1998; Ellert and Janzen, 1999). In addition, soil preparation significantly decreased soil bulk density (Table 2). Soils under plough generally have lower soil bulk density and associated higher total porosity within the plough layer than under no plough (Lipiec et al., 2006). In these iron-rich red soils, soil texture is divided into $2.0-0.05 \mathrm{~mm}$ (17\%), $0.05-0.002 \mathrm{~mm}$ (68\%), and $<0.002 \mathrm{~mm}$ (15\%) (Wen et al., 2010), soil aeration might be an important limiting factor.

In this study, the annual mean $R_{\mathrm{S}}$ rate and annual cumulative $R_{\mathrm{S}}$ per hectare of spot soil preparation treatment were significantly lower than those of the overall soil preparation treatment and were not significantly different from those of the control. Laganière et al. (2010) analyzed the experienced low and high intensity pre-planting disturbance and found that minimizing the disturbance associated with the preparation of the plantation site can increase the soil C stock by $15 \%$. Bulmer et al. (1998) and Prescott et al. (2000) suggested that site preparation affects soil C stock not only by the intensity of soil preparation but also by the total disturbed area. Although the plough depth of spot soil preparation was deeper than that of overall soil preparation, the disturbed area for spot soil preparation was only $625 \mathrm{~m}^{2}$ for 1 ha of forestation area under the assumption of a planting density of 2500 trees ha ${ }^{-1}$. Thus, it is reasonable to have less of an effect of spot soil preparation than overall soil preparation on the soil annual cumulative $R_{\mathrm{S}}$.

\subsection{Temporal dynamics in soil C release after site preparation}

When the $R_{\mathrm{S}}$ was compared between controlled burning and brush clearing, no obvious differences were found during the first four months, which is inconsistent with our third hypothesis. This phenomenon has also been reported in other studies. For example, Guo et al. (2010) found no significantly differences of $R_{\mathrm{S}}$ during the first 3-4 months after clear-cutting and controlled burning. In our experiment, controlled burning generally lasted less than $20 \mathrm{~min}$ because large shrubs and trees were removed from the experimental plots. Therefore, the root system of plants should not be significantly affected because we had to remove the regenerated grasses frequently to keep it clean for the controlled burning plots during 
the initial stage experimental period. In addition, there was no difference in the microbial biomass $C$ of the soil surface between the two treatments (Table 2) due to the relatively short heat exposure. Meanwhile, ash deposition following burning increases the availability of inorganic nutrients in soil, which could stimulate microbial growth (Peay et al., 2009). However, ash deposition had only a relatively short-term effect on the microbial community (Zimmermann and Frey, 2002). Therefore, the $R_{\mathrm{S}}$ in the controlled burning treatment decreased markedly and maintained a significantly lower level for three months compared to brush clearing (Fig. 2) from the fifth month.

$R_{\mathrm{S}}$ increased by soil preparation during the initial stage of treatment and maintained a significantly higher level compared to that of the control in the first year. However, there were no significant differences in the $R_{\mathrm{S}}$ among the soil preparation treatments in the second year. These results support our third hypothesis. Consistent with our findings, Mallik and Hu (1997) reported that the effects of site preparation on $R_{\mathrm{S}}$ lasted 5 months. However, some studies have suggested that the effects of site preparation on $R_{\mathrm{S}}$ last shorter or longer than in our study (Guo et al., 2010; Zummo and Friedland, 2011). These contradictory results may be attributed to the difference of the soil slope, soil type, climate, and decomposition rate. For example, Guo et al. (2010) found that site preparation significantly decreased the $R_{\mathrm{S}}$ during a two-year experiment that was conducted in widespread steep slopes with heavy rainfall. Soil erosion is the main path of soil $\mathrm{C}$ loss during site preparation (Black and Harden, 1995). In this study, the experiment was conducted on a flat area in which soil $\mathrm{C}$ may not be affected by soil erosion after soil preparation.

In subtropical, the litter decomposition rate is fast due to the high temperatures and abundant precipitation (Wang et al., 2009). Wang et al. (2010) found that about 75\% of initial leaf litter masses and 55\% of initial fine root masses were lost after one year. Site preparation buries litters in the soil, which may increase the decomposition rate (Kuzyakov, 2006). In our study, the amount of residues was not quantified, but we removed all of the aboveground plants, just left some slash residues and litters. In addition, there was no fresh organic matter input after treatment because regenerated plants were cleared frequently. Therefore, the contribution of organic matter decomposition to the $R_{\mathrm{S}}$ decreased to almost zero and no significant differences were found among treatments in the second year.

\section{Conclusions}

The site preparation treatments affected $R_{\mathrm{S}}$ and thus the soil $\mathrm{C}$ stock. However, significant effects of site preparation on $R_{\mathrm{S}}$ were only observed in the first year. For site clearing processes, controlled burning significantly decreased the annual cumulative $R_{\mathrm{S}}$, but the total $C$ release ( $R_{\mathrm{S}}$ and $C$ release of biomass burning) was significantly higher than that of brush clearing. The overall soil preparation treatment stimulated annual cumulative $R_{\mathrm{S}}$ compared to that of the control in both brush clearing and controlled burning plots. The spot soil preparation had no significant effect on the annual cumulative $R_{\mathrm{S}}$ due to the small area of disturbed soil. We also found the relationships between $R_{\mathrm{S}}$ and soil environmental variables varied among the different treatments. In addition, our observations indicate that the relationships between $R_{\mathrm{S}}$ and $T_{\mathrm{S}}$ can be weakened by soil preparation. Based on our results, brush clearing following spot soil preparation might be a good choice for site preparation in reducing soil $\mathrm{C}$ loss before afforestation.

\section{Acknowledgments}

This work was financially supported by the National Natural Science Foundation of China (Project No. 31070559; 31300381), the NSFC Projects of International Cooperation and Exchanges (31210103920), the Strategic Priority Research Program of the Chinese Academy of Sciences: Carbon Budget and Relevant Issures (XDA05070302), and the Gan-Po Distinguished Researcher Program.

\section{References}

Andreae, M.O., 1991. Biomass burning: its history, use and distribution and its impact on environmental quality and global climate. In: Levine, J.S. (Ed.), Global Biomass Burning: atmospheric, Climatic, and Biospheric Implications. The MIT Press, Cambridge, Massachusetts, pp. 1-21.

Badía, D., Martí, C., 2003. Effect of simulated fire on organic matter and selected microbiological properties of two contrasting soils. Arid Land Res. Manage. 17 55-69.

Bernoux, M., Cerri, C.C., Cerri, C.E.P., et al., 2006. Cropping systems, carbon sequestration and erosion in Brazil: a review. Agron. Sustain. Dev. 26, 1-8.

Berthrong, S.T., Pineiro, G., Jobbágy, E.G., Jackson, R.B., 2012. Soil C and N changes with afforestation of grasslands across gradients of precipitation and plantation age. Ecol. Appl. 22, 76-86.

Black, T.A., Harden, J.W., 1995. Effect of timber harvest on soil carbon storage at Blodgett Experimental Forest, California. Can. J. Forest Res. 25, 1385-1396.

Boerner, R.E., Decker, K.L., Sutherland, E.K., 2000. Prescribed burning effects on soil enzyme activity in a southern Ohio hardwood forest: a landscape-scale analysis. Soil Biol. Biochem. 32, 899-908.

Bulmer, C., Schmidt, M.G., Kishchuk, B., Preston, C.M., 1998. Impacts of Blading and Burning Site Preparation on Soil Properties and Site Productivity in the SubBoreal Spruce Zone of Central British Columbia, vol. 377. Pacific Forestry Centre Victoria, BC, Canada.

Certini, G., 2005. Effects of fire on properties of forest soils: a review. Oecologia 143, $1-10$.

Chapin III, F.S., Callaghan, T.V., Bergeron, Y., Fukuda, M., Johnstone, J.F., Juday, G., Zimov, S.A., 2004. Global change and the boreal forest: thresholds, shifting states or gradual change? Ambio 33, 361-365.

Davidson, E.A., Savage, K., Bolstad, P., Clark, D.A., Curtis, P.S., Ellsworth, D.S., Zak, D. 2002. Belowground carbon allocation in forests estimated from litterfall and IRGA-based soil respiration measurements. Agr. Forest Meterorol. 113, 39-51.

Davidson, E.C., Belk, E., Boone, R.D., 1998. Soil water content and temperature as independent or confounded factors controlling soil respiration in a temperate mixed hardwood forest. Glob. Chan. Boil. 4, 217-227.

Dijkstra, F.A., Cheng, W., Johnson, D.W., 2006. Plant biomass influences rhizosphere priming effects on soil organic matter decomposition in two differently managed soils. Soil Biol. Biochem. 38, 2519-2526.

Dixon, R.K., Brown, S., Houghton, R.A., Solomon, A.M., Trexler, M.C., Wisniewski, J., 1994. Carbon pools and flux of global forest ecosystems. Science 263, 185-190.

Ellert, B.H., Janzen, H.H., 1999. Short-term influence of tillage on $\mathrm{CO}_{2}$ fluxes from a semi-arid soil on the Canadian Prairies. Soil Till. Res. 50, 21-32.

Fang, J.Y., Chen, A.P., Peng, C.H., 2001. Changes in forest biomass carbon storage in China between 1949 and 1998. Science 292, 2320-2322.

Feller, C., Beare, M.H., 1997. Physical control of soil organic matter dynamics in the tropics. Geoderma 79, 69-116.

Fernández, I., Cabaneiro, A., Carballas, T., 1997. Organic matter changes immediately after a wildfire in an Atlantic forest soil and comparison with laboratory soil heating. Soil Biol. Biochem. 29, 1-11.

Fernández, I., Cabaneiro, A., Carballas, T., 1999. Carbon mineralization dynamics in soils after wildfires in two Galician forests. Soil Biol. Biochem. 31, 1853-1865.

Fritze, H., Smolander, A., Levula, T., Kitunen, V., Malkonen, E., 1994. Wood-ash fertilization and fire treatments in a Scats pine forest stand: effects on the organic layer, microbial biomass, and microbial activity. Biol. Fert. Soils 17, $51-$ 63.

González-Pérez, J.A., González-Vila, F.J., Almendros, G., Knicker, H., 2004. The effect of fire on soil organic matter - a review. Environ. Internat. 30, 855-870.

Guo, J., Yang, Y., Chen, G., Xie, J., Gao, R., Qian, W., 2010. Effects of clear-cutting and slash burning on soil respiration in Chinese fir and evergreen broadleaved forests in mid-subtropical China. Plant Soil 333, 249-261.

Guo, J.F., Yang, Y.S., Chen, G.S., Xie, J.S., Lin, P., 2006. Soil C and N pools in Chinese fir and evergreen broadleaf forests and their changes with slash burning in midsubtropical China. Pedosphere 16, 56-63.

Guo, L.B., Gifford, R.M., 2002. Soil carbon stocks and land use change: a metaanalysis. Glob. Chan. Boil. 8, 345-360.

Hamman, S.T., Burke, I.C., Stromberger, M.E., 2007. Relationships between microbial community structure and soil environmental conditions in a recently burned system. Soil Biol. Biochem. 39, 1703-1711.

Huang, M., Ji, J.J., Li, K.R., Liu, Y.F., Yang, F.T., Tao, B., 2007. The ecosystem carbon accumulation after conversion of grasslands to pine plantations in subtropical red soil of South China. Tellus B 3, 439-448.

Hubbard, R.M., Vose, J.M., Clinton, B.D., Elliot, K.J., Knoepp, J.D., 2004. Stand restoration burning in oak-pine forests in the southern Appalachians: effects on aboveground biomass and carbon and nitrogen cycling. Forest Ecol. Manage. $190,311-321$.

Huntington, T.G., Center, P.B., 1995. Carbon Sequestration in an aggrading forest ecosystem in the southeastern USA. Soil Sci. Soc. Am. J. 59, 1459-1467.

IPCC, 2007. IPCC Special Report on Land Use, Land-Use Change and Forestry. University Press, Cambridge. 
Johansson, M.B., 1994. The influence of soil scarification on the turn-over rate of slash needles and nutrient release. Scand. J. Forest Res. 9, 170-179.

Johnson, D.W., Curtis, P.S., 2001. Effects of forest management on soil C and N storage: meta-analysis. Forest Ecol. Manage. 140, 227-238.

Karlsson, A., 2002. Site preparation of abandoned fields and early establishment of planted small-sized seedlings of silver birch. New Forest. 23, 159-175.

Kuzyakov, Y., 2006. Sources of $\mathrm{CO}_{2}$ efflux from soil and review of partitioning methods. Soil Biol. Biochem. 38, 425-448.

Laganière, J., Angers, D.A., Pare, D., 2010. Carbon accumulation in agricultural soils after afforestation: a meta-analysis. Glob. Chan. Biol. 16, 439-453.

La Scala, N., Lopes, A., Panosso, A.R., Câmara, F.T., Pereira, G.T., 2005. Soil $\mathrm{CO}_{2}$ efflux following rotary tillage of a tropical soil. Soil Till. Res. 84, 222-225.

La Scala, N., Lopes, A., Spokas, K., Bolonhezi, D., Archer, D.W., Reicosky, D.C., 2008. Short-term temporal changes of soil carbon losses after tillage described by a first-order decay model. Soil Till. Res. 99, 108-118.

Lavee, H., Kutiel, P., Segev, M., Benyamini, Y., 1995. Effect of surface roughness on runoff and erosion in a Mediterranean ecosystem: the role of fire. Geomorphology 11, 227-234.

Li, D. Niu, S., Luo, Y., 2012. Global patterns of the dynamics of soil carbon and nitrogen stocks following afforestation: a meta-analysis. New Phytol. 195, 172 181.

Lipiec, J., Kuś, J., Słowińska-Jurkiewicz, A., Nosalewicz, A., 2006. Soil porosity and water infiltration as influenced by tillage methods. Soil Till. Res 89 (2) 210-220.

Lundmark-Thelin, A., Johansson, M.B., 1997. Influence of mechanical site preparation on decomposition and nutrient dynamics of Norway spruce (Piced abies (L.) Karst.) needle litter and slash needles. Forest Ecol. Manage. 96, 101110.

Ma, S.Y., Chen, J., North, M., Erickson, H.E., Bresee, M., Le Moine, J., 2004. Short-term effects of experminetal burning and thinning on soil respiration in an oldgrowth, mixed-conifer forest. Environ. Manage. 33, S148-S159.

Mallik, A.U., Hu, D., 1997. Soil respiration following site preparation treatments in boreal mixed-wood forest. Forest Ecol. Manage. 97, 265-275.

Martin, D.A., Moody, J.A., 2001. Comparison of soil infiltration rates in burned and unburned mountains watersheds. Hydrol. Proc. 15, 2893-2903.

Mataix-Solera, J., Cerdà, A., Arcenegui, V., Jordán, A., Zavala, L.M., 2011. Fire effects on soil aggregation: a review. Earth Sci. Rev. 109, 44-60.

McCarthy, D.R., Brown, K.J., 2006. Soil respiration responses to topography, canopy cover, and prescribed burning in an oak-hickory forest in southeastern Ohio. Forest Ecol. Manage. 237, 94-102.

McLaughlin, J.B., Gale, M.R., Jurgensen, M.F., Trettin, C.C., 2000. Soil organic matter and nitrogen cycling in response to harvesting, mechanical site preparation, and fertilization in a wetland with a mineral substrate. Forest Ecol. Manage. 129, 7 23.

Neary, D.G., Klopatek, C.C., Debano, L.F., 1999. Fire effects on belowground sustainability: a review and synthesis. Forest Ecol. Manage. 122, 51-71.

Nouvellon, Y., Epron, D., Kinana, A., Hamel, O., et al., 2008. Soil $\mathrm{CO}_{2}$ effluxes, soil carbon balance, and early tree growth following savannah afforestation in Congo: comparison of two site preparation treatments. Forest Ecol. Manage. 255, 1926-1936.

Paul, K.I., Polglase, P.J., Nyakuengama, J.G., Khanna, P.K., 2002. Change in soil carbon following afforestation. Forest Ecol. Manage. 168, 241-257.

Paul, K.I., Polglase, P.J., Richard, G.P., 2003. Predicted change in soil carbon following afforestation or reforestation, and analysis of controlling factors by linking a C accounting model (CAMF or) to models of forest growth (3PG), litter decomposition (GENDEC) and soil C turnover (RothC). Forest Ecol. Manage. $177,485-501$

Peay, K.G., Garbelotto, M., Bruns, T.D., 2009. Spore heat resistance plays an important role in disturbance-mediated assemblage shift of ectomycorrhizal fungi colonizing Pinus muricata seedlings. J. Ecol. 97, 537-547.

Pérez-Batallón, P., Ouro, G., Macías, F., Merino, A., 2001. Initial mineralization of organic matter in a forest plantation soil following different logging residue management techniques. Ann. For. Sci. 58, 807-818.

Phillips, R.L., Zak, D.R., Holmes, W.E., White, D.C., 2002. Microbial community composition and function beneath temperate trees exposed to elevated atmospheric carbon dioxide and ozone. Oecologia 131, 236-244.

Pietikäinen, J., Fritze, H., 1995. Clear-cutting and prescribed burning in coniferous forest: comparison of effects on soil fungal and total microbial biomass, respiration activity and nitrification. Soil Biol. Biochem. 27, 101-109.

Post, W.M., Emanuel, W.R., Zinke, P.J., Stangenberger, A.G., 1982. Soil carbon pools and world life zones. Lett. Nat., 156-159.
Post, W.M., Kwon, K.C., 2000. Soil carbon sequestration and land-use change: processes and potential. Glob. Chan. Boil. 6, 317-327.

Prescott, C.E., Maynard, D.G., Laiho, R., 2000. Humus in northern forests: friend or foe? Forest Ecol. Manage. 133, 23-26.

Pumpanden, J., Westman, C.J., Iivesniemi, $\mathrm{H}$., 2004. Soil $\mathrm{CO}_{2}$ efflux from a podzolic forest soil before and after forest clear-cutting and site preparation. Boreal Environ. Res. 9, 199-212.

Pumpanen, J., 2003. $\mathrm{CO}_{2}$ Efflux From Boreal Forest Soil Before and After ClearCutting and Site Preparation. University of Helsinki, Finland.

Salonius, P.O., 1983. Effects of organic-mineral soil mixtures and increasing temperature on the respiration of coniferous raw humus material. Can. J. Forest Res. 13, 102-107.

Seiler, W., Crutzen, P.J., 1980. Estimates of gross and net fluxes of carbon between the biosphere and the atmosphere from biomass burning. Climatic Change 2, 207-247.

Six, J., Feller, C., Denef, K., Ogle, S., Sa, J.C.D.M., Albrecht, A., 2002. Soil organic matter, biota and aggregation in temperate and tropical soils-effects of no-tillage. Agronomie 22, 755-775.

Strömgren, M., Mjöfors, K., 2012. Soil- $\mathrm{CO}_{2}$ flux after patch scarification, harrowing and stump harvest in a hemi-boreal forest. Scand. J. Forest Res. 27, 754-761.

Sun, Y., Wu, J., Shao, Y., Zhou, L., Mai, B., Lin, Y., Fu, S., 2011. Responses of soil microbial communities to prescribed burning in two paired vegetation sites in southern China. Ecol. Res. 26, 669-677.

Thorburn, P.J., Probert, M.E., Robertson, F.A., 2001. Modeling decomposition of sugar cane surface residues with APSIM-Residue. Field Crops Res. 70, 223-232.

Treseder, K.K., Mack, M.C., Cross, A., 2004. Relationships amongfires, fungi, and soil dynamics in Alaskan boreal forests. Ecol. Appl. 14, 1826-1838.

Trouvé, C., Mariotti, A., Schwartz, D., Guillet, B., 1994. Soil organic carbon dynamics under Eucalyptus and Pinus planted on savannahs in the Congo. Soil Biol. Biochem. 26, 287-295.

Vance, E.D., Brookes, P.C., Jenkinson, D.S., 1987. An extraction method for measuring soil microbial biomass C. Soil Biol. Biochem. 19, 703-707.

Vesterdal, L., Ritter, E., Gundersen, P., 2002. Change in soil organic carbon following afforestation of former arable land. Forest Ecol. Manage. 169, 137-147.

Wang, Y.D., Wang, H.M., Ma, Z.Q., et al., 2009. Contribution of aboveground litter decomposition to soil respiration in a subtropical coniferous plantation in southern China. Asia-Pac. J. Atmos. Sci. 45, 137-147.

Wang, H., Liu, S.R., Mo, J.M., 2010. Correlation between leaf litter and fine root decomposition among subtropical tree species. Plant Soil 335, 289-298.

Wang, Y.D., Li, Q.K., Wang, H.M., Wen, X.F., Yang, F.T., Ma, Z.Q., Liu, Y.F., Sun, X.M., Yu, G.R., 2011. Precipitation frequency controls inter annual variation of soil respiration by affecting soil moisture in a subtropical forest plantation. Can. J. For. Res. 41, 1897-1906.

Wang, Y.D., Wang, Z.L., Wang, H.M., Guo, C.C., Bao, W.K., 2012a. Rainfall pulse primarily drives litterfall respiration and its contribution to soil respiration in a young exotic pine plantation in subtropical China. Can. J. For. Res. 42, 657-666.

Wang, O.K. Zhong, M.C., Wang, S.L., 2012b. A meta-analysis on the response of microbial biomass, dissolved organic matter, respiration, and $\mathrm{N}$ mineralization in mineral soil to fire in forest ecosystems. Forest Ecol. Manage. 271, 91-97.

Wang, Y.D., Wang, H.M., Ma, Z.Q., Dai, X.Q., Wen, X.F., Liu, Y.F., Wang, Z.L., 2013. The litter layer acts as a moisture-induced bidirectional buffer for atmospheric methane uptake by soil of a subtropical pine plantation. Soil Biol. Biochem. 66, 45-50.

Wen, X.F., Wang, H.M., Wang, J.L., Yu, G.R., Sun, X.M., 2010. Ecosystem carbon exchanges of a subtropical evergreen coniferous plantation subjected to seasonal drought, 2003-2007. Biogeosciences 7, 357-369.

Wuthrich, C., Schaub, D., Weber, M., Marxer, P., Conedera, M., 2002. Soil respiration and soil microbial biomass after fire in a sweet chestnut forest in southern Switzerland. Catena 48, 201-215.

Xu, M., Qi, Y., 2001. Spatial and seasonal variations of $Q_{10}$ determined by soil respiration measurements at a Sierra Nevadan forest. Glob. Biogeochem. Cycl. $15,687-696$.

Yang, Y.S., Guo, J., Chen, G., Xie, J., Gao, R., Li, Z., Jin, Z., 2005. Carbon and nitrogen pools in Chinese fir and evergreen broadleaved forests and changes associated with felling and burning in mid-subtropical China. Forest Ecol. Manage. 216, $216-226$.

Zimmermann, S., Frey, B., 2002. Soil respiration and microbial properties in an acid forest soil: effects of wood ash. Soil Bio. Biochem. 34, 1727-1737.

Zummo, L.M., Friedland, A.J., 2011. Soil carbon release along a gradient of physical disturbance in a harvested northern hardwood forest. Forest Ecol. Manage. 261, 1016-1026. 